\title{
State of knowledge and conservation of the snake fauna of the "Brejos de Altitude" in the Pernambuco Endemism Center, Northeastern Brazil
}

Gentil Alves Pereira Filho ${ }^{1 *}$, Marco Antônio de Freitas ${ }^{2}$, Washington Luiz Silva Vieira ${ }^{3}$, Geraldo Jorge Barbosa de Moura ${ }^{4}$ and Frederico Gustavo Rodrigues França ${ }^{5}$

\begin{abstract}
The Atlantic Forest is originally distributed along the Brazilian coast from the states of Rio Grande do Norte to Rio Grande do Sul, and it presents many different vegetal physiognomies. Brejos de Altitude is a set of relict altitudinal forests in northeastern Brazil with a distinct and poorly studied biota representing special areas within the Atlantic Forest. The snake fauna of these forests is still poorly understood despite the increasing amount of information available. The aim of this study was to furnish the current state of knowledge and conservation of the snake fauna at the Brejos in the Pernambuco Endemism Center. The database used here is based on the materials housed at Museu de Zoologia da Universidade de São Paulo and the herpetological collections of Universidade Federal da Paraíba and Universidade Federal Rural de Pernambuco, in addition to literature records. Out of 7 families, 37 genera and 63 species were found in Brejos de Altitude, and no species appeared in the list of endangered fauna of Brazil. The results showed species with strong dependence on forest and species distributed in open areas, such as Caatinga and Cerrado, although, many Brejos showed no data on snake fauna. In conclusion, Brejos de Altitude is a threatened region of the Atlantic Forest with a small number of protected areas and high rates of deforestation, thus needing urgent conservation actions.
\end{abstract}

Keywords: Endemism; Snakes; Conservation

\begin{abstract}
1 Núcleo de Ecologia de Serpentes, Laboratório de Ecologia Animal, Centro de Ciências Aplicadas e Educação, Universidade Federal da Paraíba- UFPB, Av. Santa Elizabete, s/n - Cebtro. CEP 58297-000, Rio Tinto, PB, Brazil. https://orcid.org/00000002-0164-3898

2 Instituto Chico Mendes de Conservação da Biodiversidade (ICMBIO), ESEC Murici, Rua Marino Vieira de Araújo 32, Cidade Alta, CEP 57820-000, Murici, AL, Brazil

3 Laboratório de Ecofisiologia Animal, Departamento de Sistemática e Ecologia, Centro de Ciências Exatas e da Natureza, Universidade Federal da Paraíba, Campus I, João Pessoa, PB, Brazil, CEP 58059-970. https://orcid.org/0000-0002-0673-262X

4 Universidade Federal Rural de Pernambuco, Laboratório de Estudos Herpetológicos e Paleoherpetológicos, Rua Dom Manuel de Medeiros, s/n, Dois Irmãos, cep 52171-900, Recife, PE, Brazil

5Departamento de Engenharia e Meio Ambiente, Centro de Ciências Aplicadas e Educação, Universidade Federal da ParaíbaUFPB, Av. Santa Elizabete, s/n - Centro. CEP 58297-000, Rio Tinto, PB, Brazil. https://orcid.org/0000-0001-6989-2455
\end{abstract}

* Corresponding author. $\bowtie \mathrm{E}$-mail address: gentilfilho@yahoo.com

\section{SIGNIFICANCE STATEMENT}

The manuscript addresses the sate of knowledge of the snake fauna in the Pernambuco Endemism Center, the most vulnerable sector of the Atlantic Forest, particularly in the "Brejos de Altitude", fragments of Atlantic Forest in the semiarid region known as Caatinga. The main contribution of the manuscript is to put some light in the biogeographic relations of the snake fauna of the Atlantic Forest. The results shown a division within the "Brejos", with humid and dry inland forests. Others results shown that the "Brejos" are closer to coastal Atlantic Forest than the Caatinga region. After 9 years, this is the second overview of the snake fauna of the "Brejos". In that occasion were known 5 families, 22 genera and 27 species for 8 "Brejos". Now there are known 7 families, 37 genera and 63 species for 16 "Brejos". These data can contribute to protect such singular areas. 


\section{INTRODUCTION}

Biodiversity study is an important aspect to preserve natural landscapes and increase our knowledge of the complexity of ecosystem structures in nature. Currently, owing to rapid destruction, many ecosystems are considered hotspots to be highly threatened, and the Atlantic Forest fits in this perspective. The Atlantic Forest is one of the most diverse tropical forests of the world, with an impressive number of endemic species of many zoological groups, such as mammals, birds, amphibians, and reptiles (Myers et al. 2000). Originally, this forest was distributed along the Brazilian coast extending from the states of Rio Grande do Norte to the Rio Grande do Sul, and it presented various vegetal physiognomies or biogeographic units (Pereira-Filho et al. 2017). One of these units is northeastern Atlantic Forest, also known as the Pernambuco Endemism Center (PEC), which includes the "Brejos de Altitude". The forests of the PEC are restricted to an area from the states of Alagoas to Rio Grande do Norte encompassing coastal and inland forests (Thomas and Barbosa 2008).

Brejos de Altitude, also called submontane tropical moist forests, are relict forests distributed in northeastern Brazil, specifically in the semiarid region known as Caatinga, and are considered disjunctions between the Atlantic Forest and Amazon, which occur in mountains at an elevation ranging from 100 to $600 \mathrm{~m}$ with higher annual precipitation than the surrounding semiarid landscape (Andrade-Lima 1982; Thomas and Barbosa 2008; Pereira-Filho and Montingelli 2011). These forests act as refuges, and they harbor high biodiversity of species from Caatinga, Atlantic Forest, and Amazon. In the PEC, 31 Brejos de Altitude represent $22 \%$ of all northeastern Brejos (Tabarelli and Santos 2004).

Despite the high number of Brejos de Altitude, the snake fauna of these forest "islands" is not well known, and information about ecology, biogeography and taxonomy is scarce (Pereira-Filho and Montingelli 2011). Information on the snake fauna of the PEC is also scarce if compared with that of the southeastern portion of the biome (Pereira-Filho et al. 2017). Recently, this panorama started to change with increasing number of published data on snake fauna (Pereira-Filho and Montingelli 2011; França et al. 2012; Rodrigues et al. 2015; PereiraFilho et al. 2017; Roberto et al. 2017; Sampaio et al. 2018; Freitas et al. 2019). However, even as the number of contributions increases, many areas are not yet sampled, nor record information is available in the literature or in scientific collections. The first specific overview of the snakes of Brejos de Altitude was published in 2011 (Pereira-Filho and Montingelli 2011). Since then, only in 2019 was another information on some Brejos in the Pernambuco state published (Freitas et al. 2019).

Besides the lack of species lists and inventories, conservation of the snake fauna of Brejos is also a source of great concern, as few measures have been taken to assure the viability of the biodiversity of such important ecosystems. Many Brejos suffer from heavy deforestation, fragmentation, and a decrease in area (Pereira-Filho and Montingelli 2011). These problems are present all over the Atlantic Forest, but are more serious in small areas such as Brejos.

This study aimed to analyze the state of knowledge of the snake fauna of the Brejos in the PEC, understand how the snake fauna is related to those of Caatinga and the Atlantic Forest and finally generate a list of 
species recorded in these areas (Rizzini 1963; Vanzolini 1981; Andrade-Lima 1982; Prance 1982; Tabarelli and Santos 2004; Rodal et al. 2008; Pereira-Filho and Montingelli 2011; Guedes et al. 2014). We also analyzed possible differences within the Brejos, verifying the findings of Rodal et al. (2008) on the probable existence of humid and dry Brejos, as well as examined the conservational aspects of the snakes of the region.

\section{MATERIAL AND METHODS}

The study site comprises remnants of Brejos de Altitude located in the states of Paraíba, Pernambuco, and Alagoas, an area known as the PEC (Figure 1). The data presented herein represent the snake fauna of 16 Brejos de Altitude. The definitions of the areas considered as Brejos de Altitude follow those of Tabarelli and Santos (2004), Thomas and Barbosa (2008), and PereiraFilho and Montingelli (2011).

To obtain a list of species, we examined specimens from three herpetological collections: the herpetological collection of Universidade Federal da Paraíba (CHUFPB), the herpetological collection of Museu de Zoologia da Universidade de São Paulo (MZUSP), and the herpetological collection of Universidade Federal Rural de Pernambuco (CHPUFRPE). Together, these three collections allowed us to examine 265 exemplars of 36 species of 16 Brejos: 6 in Paraíba and 10 in Pernambuco. Some species were provided from photographic or direct observation in the areas and were not collected due to lack of collecting permission (11 species). The material housed in these three collections was the main source of our list, although we added information from

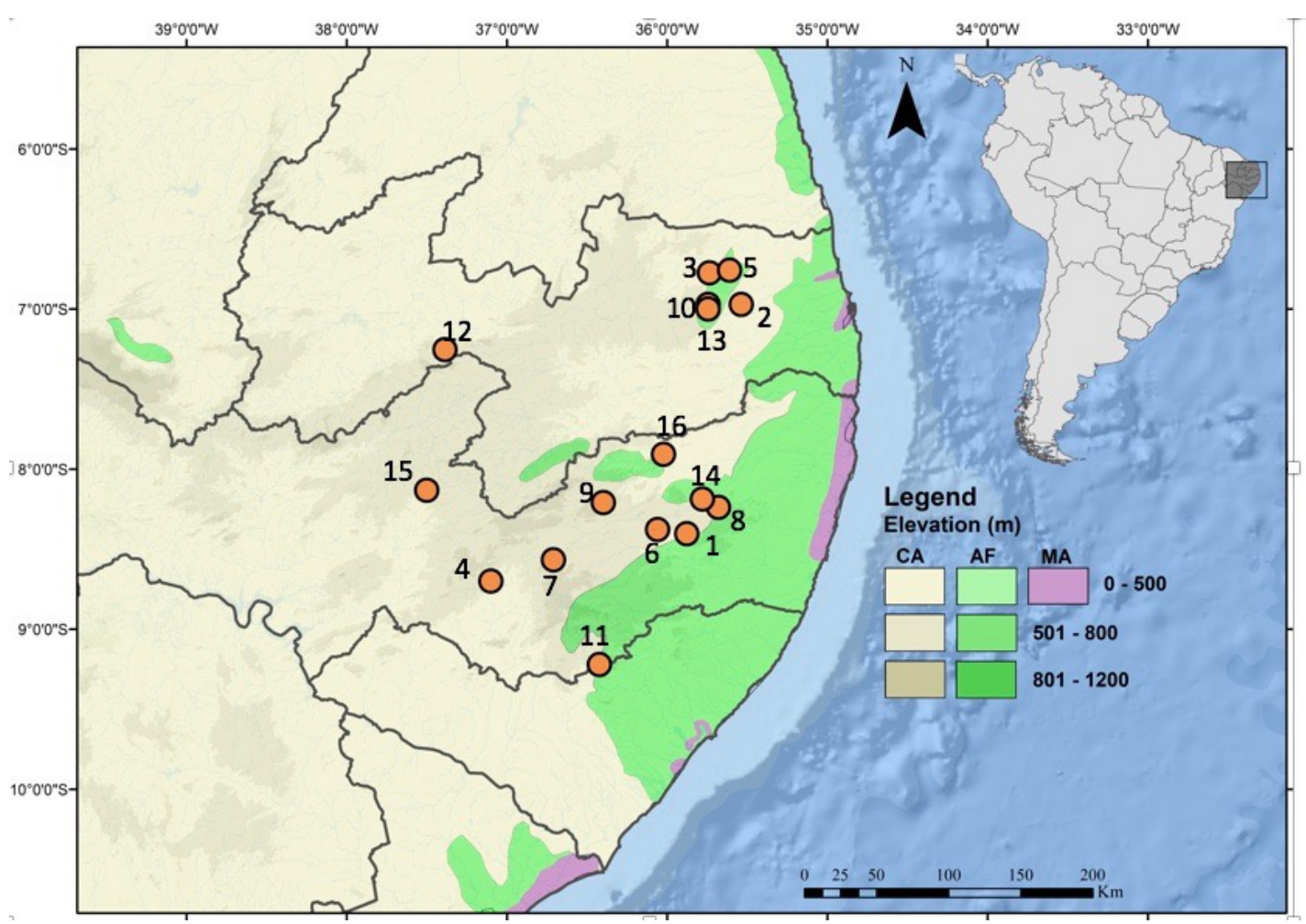

Figure 1. Map showing the localities of the Brejos de Altitude with information about the snake fauna in PEC. Numbers correspond to each locality. 1- Agrestina, 2- Alagoinha, 3- Arara, 4- Arcoverde, 5Bananeiras, 6- Brejo dos Cavalos, 7- Belo Jardim, 8- Bezerros, 9- Madre de Deus, 10- Areia (Pau Ferro), 11- Pedra Talhada, 12- Pico do Jabre, 13, Alagoa Grande, 14- Serra Negra, 15- Sertânea, 16Taquaritinga do Norte. 
recently published literature (Pereira-Filho and Montingelli 2011; Roberto et al. 2015; Freitas et al. 2019). With the addition of literature data, 16 new species were added to the Brejos, increasing the final number of species to 63 (see table 1 for detailed information).

The material housed in the CHUFPB, MZUSP, and UFRPE had its identification confirmed by authors using specialized literature (Cunha and Nascimento 1978; Peters and Orejas-Miranda 1970; PereiraFilho et al. 2017). The taxonomic arrangement follows that of Zaher et al. (2009) and Costa and Bernils (2018).

To verify the singularity of the Brejos and their relationship with the Caatinga and the coastal Atlantic Forest, two neighbor-joining analyses (nearest neighbor-joining, Euclidian distance index) were performed using the software PAST for Mac with the Euclidean distance as index. Eight of the most wellsampled Brejos were utilized to verify the existence of humid and dry Brejos. To verify if the similarity of snake's composition found in cluster analysis merely reflects the geographical distance between brejos areas, that is, closer areas will be more similar than distant areas, we used a linear regression analysis between the dissimilarity index (of Euclidian distance generated by the cluster analysis) and the geographical distances (Table 2)

To investigate the relationship of the Brejos with the Caatinga and the northeastern coastal Atlantic Forest, we examined nine snake assemblages located in Caatinga: RPPN Fazenda Almas, São João do Cariri, Imaculada, Pedra da Bola, Olho D'Água Branco (Pereira-Filho et al. 2017), Exu (Vitt and Vangilder 1983), Catimbau (Pedrosa et al. 2014), Juazeiro (Freitas et al. 2016), and Serra de Santa Catarina (Abrantes et al. 2018), as well as seven located in the northeastern coastal Atlantic Forest: Sema II, Mata do Buraquinho, RPPN Gargau, Mata da Usina São João, Sema III (Pereira-Filho et al. 2017), Parque Dois Irmãos (Melo et al. 2018), and Serra do Urubu (Roberto et al. 2017). In both analyses, we utilized a matrix of presence and absence for 266 species. To avoid sample discrepancies, we utilized only the most well-sampled locations with robust lists and correct identification of species as well as unpublished data of the authors.

\section{RESULTS AND DISCUSSION}

The biota of Brejos de Altitude (also known as Brejos Nordestinos) has been long discussed, although few new data have been incorporated into this discussion. Many studies have provided information about plants in the Brejos (Andrade-Lima, 1960; 1966), which is the basis of many interpretations of the forest refuges, owing to the expansions and retractions of humid forests in the Pleistocene, forming humid forest islands in isolated plateaus and mountain ranges with varying altitudes from 600 to $1200 \mathrm{~m}$ (Bigarella et al. 1975; Andrade-Lima 1982; Lins 1989; Tabarelli and Santos 2004).

The first specific approach to record the snake fauna of the Brejos de Altitude in the PEC was conducted by Pereira-Filho and Montingelli (2011). These authors recorded 5 families, 22 genera, and 27 species in 8 Brejos: 4 in Paraíba and 4 in Pernambuco. They mentioned that this richness was certainly an underestimation of the real number of snake species in all Brejos. After almost 10 years, information on the snake fauna of Brejos is still scarce, but much information has been added to the subject.

In this study, we recorded 7 families, 37 genera, and 63 species in 16 Brejos in the 
PEC (Table 1). The present number of species represented a significant increase (more than double) compared with that presented 9 years ago (Pereira-Filho and Montingelli 2011). Many species were recorded for the first time in the Brejos (a total of 36 new records), such as Atractus caete, Boiruna sertaneja, and Taeniophallus affinis, showing the scarcity of information. Vanzolini (1981) stated that each Brejo presents a specific set of fauna, and despite the increase in species number, which improves our knowledge, the number of sampled areas continues to be insufficient to clarify many aspects of the snake fauna of these forests. The number of Brejos sampled increased from 8 to 16 , but most of the data came from short-time collection efforts with nonspecific methodologies for sampling snakes. With few areas sampled and the lack of long-time inventories, comparisons of the assemblages of each Brejos must be performed with caution, and the differences and similarities of these humid forests from a general perspective can only be examined speculatively.

Recently, new botanical data brought a new discussion about the types of Brejos, exhibiting two different kinds of PEC inland forests. The Borborema Plateau apparently divides the Brejos into two sets according to both moisture and botanical composition. The group of Brejos located to the east of the plateau is more similar to the coastal Atlantic Forest, sharing a high percentage of botanical species (humid Brejos) (Barbosa et al. 2004). The other group of Brejos located west of the Borborema Plateau appears to be more related to the areas of the surrounding Caatinga (dry Brejos) (Rodal and Sales 2008; Rodal et al. 2008). However, owing to the scarcity of data, mainly of the Brejos at the west of the Borborema Plateau, it is difficult to generalize the botanical panorama emphasizing on the snake fauna. To verify whether the separation of Brejos in the two sets is reflected in the snake fauna, we performed a multivariate statistical analysis (Figure 2) comparing eight areas of Brejos. Despite insufficient information on the snake fauna of dry Brejos, the Caatinga snake fauna might be predominant in these areas, and the forest-dependent species were predominant in humid Brejos. With this in mind, comparisons concerning Brejos need to consider these two sets of forests to avoid inappropriate parallels. A Linear Regression

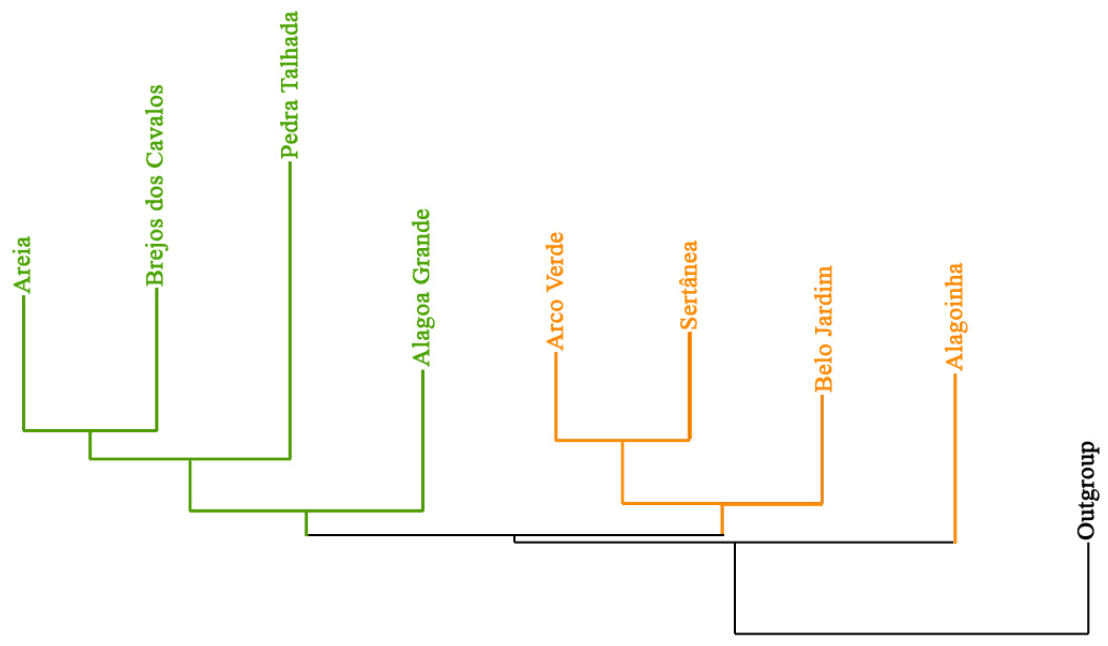

Figure 2. Neighbourn-joining analyses showing a separation of two sets of Brejos emphasizing the separation in dry and humid Brejos. Humid Brejos in green and dry in yellow. 
Table 1. List of species recorded for each Brejo de Altitude in PEC. Species with * came from literature records (Rorberto et al. 2017, Freitas et al. 2019), species with ** were provided from direct/ photographic records in the areas but without vouchers (Arara=ARA; Alagoinha=ALA, Bananeiras=BAN, Areia - Pau-Ferro=APF, Pico do Jabre=PJ, Alagoa Grande=AG, Arcoverde=ARC, Agrestina=AGR, Bezerros=BEZ, Belo Jardim=BJ, Brejo dos Cavalos=BC, Brejo da Madre de Deus=BMD, Pedra Talhada=PT, Serra Negra $=S N$, Sertânea=SER, Taquaritinga do Norte=TN)

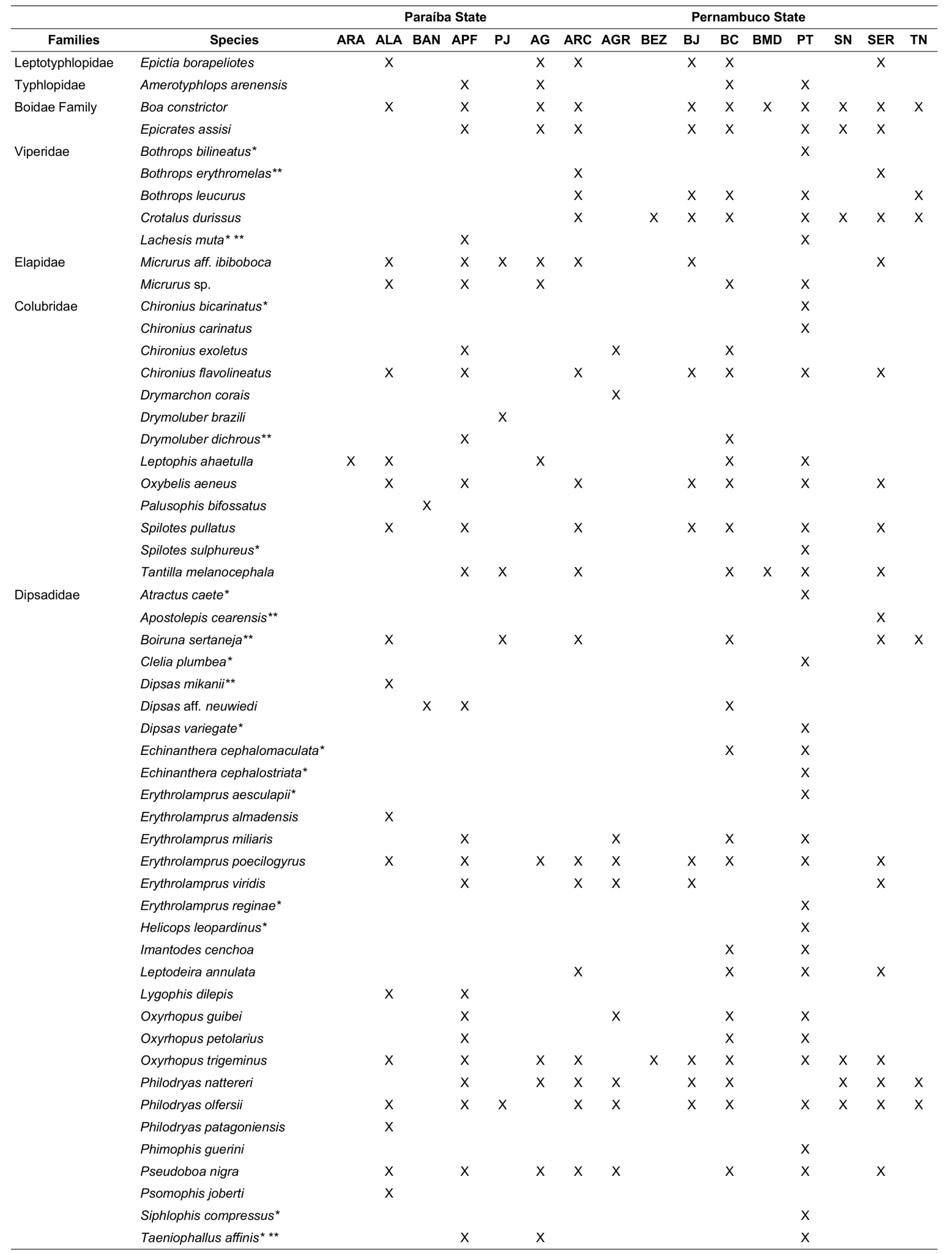




\begin{tabular}{|c|c|c|c|c|c|c|c|c|c|c|c|c|c|c|c|c|}
\hline Taeniophallus occipitalis & & & & & & & & & & & & $x$ & $x$ & & & \\
\hline Thamnodynastes almae ${ }^{* *}$ & & & & & & & $x$ & & & $x$ & $x$ & & & $x$ & $x$ & \\
\hline Thamnodynastes hypoconia & & & & $x$ & $\mathrm{x}$ & & & & & & & & & & & \\
\hline Thamnodynastes pallidus* ** & & & & & & & & & & & $x$ & & $x$ & & & \\
\hline Thamnodynastes phoenix ${ }^{* *}$ & & & & & & & $x$ & & & $x$ & & & & & $x$ & \\
\hline Thamnodynastes sertanejo** & & & & & & & $x$ & & & $x$ & & & & & $x$ & \\
\hline Xenodon merremii & & $x$ & $\mathrm{x}$ & $x$ & & $x$ & $x$ & & & $x$ & $x$ & & $x$ & & $x$ & \\
\hline Xenodon rabdocephalus* & & & & & & & & & & & & & $x$ & & & \\
\hline Xenopholis undulatus & & & & $\mathrm{x}$ & & & & & & & & & & & & \\
\hline Total $=63$ & 1 & 19 & 3 & 27 & 6 & 13 & 23 & 9 & 2 & 18 & 30 & 3 & 40 & 7 & 23 & 6 \\
\hline
\end{tabular}

Analysis indicates there is no relationship between the geographical distance among brejos and the similarity/dissimilarity in the snake composition of brejos $\left(r^{2}=0.02\right.$, $\mathrm{F} 1,26=1.65, \mathrm{P}=0.210$ ) what reinforces the faunistic characteristics of each Brejo (Table 2).

Among the 63 species recorded here, 31 are forest dwellers with distribution in the Atlantic and Amazon Forests, species such as Bothrops bilineatus, Lachesis muta, Spilotes sulphureus, Thamnodynastes pallidus, Dipsas variegata and Chironius carinatus presented disjunctive distribution between the Amazon and Atlantic Forest. The other six species are endemic to the Atlantic Forest, such as Bothrops leucurus, Atractus caete, Dipsas aff. neuwiedi, Echinanthera cephalomaculata, Chironius bicarinatus, and Echinanthera cephalostriata. Finally, 28 species presented a wide geographic distribution with records in open areas such as Caatinga (Table 3 ).

Our analyses showed differences in snake fauna between the dry and humid inland forests in the Borborema Plateau. This interpretation was based on several species. Species such as Micrurus sp., Drymoluber brazili, Bothrops erythromelas, Thamnodynastes sertanejo, Thamnodynastes phoenix, and Thamnodynastes almae, are components of dry Brejos and known to be closely related to the Caatinga biome (Marques et al. 2017). Other species such as Drymoluber dichrous, Lachesis muta, Bothrops leucurus, and Spilotes sulphureus are found in humid Brejos and in the coastal fragments of the Atlantic Forest.

Owing to years of devastation, the Atlantic Forest has lost a huge area in the northeastern and many other regions, causing a significant reduction in forests or even complete deforestation (Pereira-Filho et al. 2017). It is plausible that the coastal Atlantic Forest was connected to some humid Brejos, such as Areia (Pau Ferro) and Alagoa Grande. This connection would explain the high zoological similarities observed in this study; however, the absence of continuous areas from the coastal to the interior regions (Borborema Plateau) only allowed conjecture about this possible contact (Barbosa et al. 2004).

Table 2. Geographical distance in kilometers (Boldface) and Dissimilarity Index for Brejos de Altitude in PEC

\begin{tabular}{|c|c|c|c|c|c|c|c|c|}
\hline & Areia (Pau Ferro) & Brejo dos Cavalos & Pedra Talhada & Alagoa Grande & Arco Verde & Sertânea & Belo Jardim & Alagoinha \\
\hline Areia (Pau Ferro) & $x$ & 3.168 & 5.488 & 4.008 & 4.367 & 4.481 & 4.131 & 4.591 \\
\hline Bejo dos Cavalos & 160.25 & $x$ & 5.109 & 4.008 & 4.591 & 4.700 & 4.591 & 4.805 \\
\hline Pedra Talhada & 261.12 & 101.92 & $x$ & 5.668 & 6.094 & 6.176 & 5.927 & 6.415 \\
\hline Alagoa Grande & 20.28 & 152.67 & 254.46 & $x$ & 4.131 & 4.481 & 3.613 & 3.880 \\
\hline Arco Verde & 244.61 & 120.94 & 94.43 & 245.43 & $x$ & 2.240 & 2.834 & 4.251 \\
\hline Sertânea & 233.59 & 161.94 & 170.10 & 240.78 & 77.72 & $x$ & 3.323 & 4.367 \\
\hline Belo Jardim & 207.11 & 74.66 & 79.09 & 205.63 & 46.32 & 100.45 & $x$ & 3.471 \\
\hline Alagoinha & 22.88 & 166.59 & 268.44 & 14.12 & 259.18 & 252.89 & 219.64 & $x$ \\
\hline
\end{tabular}


Table 3. Species list of the snake fauna of Brejos de Altitude in PEC with marked distribution in Atlantic Forest, Amazon and Caatinga

\begin{tabular}{|c|c|c|c|}
\hline Families/Species & $\begin{array}{l}\text { Atlantic Forest } \\
\text { (Brejos de Altitude and } \\
\text { coastal fragments) }\end{array}$ & $\begin{array}{l}\text { Amazon and } \\
\text { Atlantic } \\
\text { Forest }\end{array}$ & Caatinga \\
\hline \multicolumn{4}{|l|}{ Leptotyphlopidae Family } \\
\hline Epictia borapeliotes & $\mathrm{x}$ & & $x$ \\
\hline \multicolumn{4}{|l|}{ Typhlopidae Family } \\
\hline Amerotyphlops arenensis & $x$ & $\mathrm{x}$ & \\
\hline \multicolumn{4}{|l|}{ Boidae Family } \\
\hline Boa constrictor & $\mathrm{x}$ & $x$ & $x$ \\
\hline Epicrates assisi & $\mathrm{x}$ & & $\mathrm{x}$ \\
\hline \multicolumn{4}{|l|}{ Viperidae Family } \\
\hline Bothrops bilineatus & $\mathrm{x}$ & $\mathrm{x}$ & \\
\hline Bothrops erythromelas & & & $x$ \\
\hline Bothrops leucurus & $\mathrm{x}$ & & \\
\hline Crotalus durissus & $\mathrm{x}$ & $\mathrm{x}$ & $\mathrm{x}$ \\
\hline Lachesis muta & $x$ & $x$ & \\
\hline \multicolumn{4}{|l|}{ Elapidae Family } \\
\hline Micrurus aff. ibiboboca & $\mathrm{x}$ & & \\
\hline Micrurus sp & & & $x$ \\
\hline \multicolumn{4}{|l|}{ Colubridae Family } \\
\hline Chironius bicarinatus & $\mathrm{x}$ & & \\
\hline Chironius carinatus & $x$ & $x$ & \\
\hline Chironius exoletus & $x$ & $x$ & \\
\hline Chironius flavolineatus & $\mathrm{x}$ & & \\
\hline Drymarchon corais & $\mathrm{x}$ & $\mathrm{x}$ & $x$ \\
\hline Drymoluber brazili & & & $x$ \\
\hline Drymoluber dichrous & $x$ & $x$ & \\
\hline Leptophis ahaetulla & $x$ & $x$ & $x$ \\
\hline Oxybelis aeneus & $x$ & $x$ & $x$ \\
\hline Palusophis bifossatus & $\mathrm{x}$ & $\mathrm{x}$ & \\
\hline Spilotes pullatus & $x$ & $x$ & $x$ \\
\hline Spilotes sulphureus & $\mathrm{x}$ & $x$ & \\
\hline Tantilla melanocephala & $x$ & $x$ & \\
\hline \multicolumn{4}{|l|}{ Dipsadidae Family } \\
\hline Atractus caete & $\mathrm{x}$ & & \\
\hline Apostolepis cearensis & $x$ & & $x$ \\
\hline Boiruna sertaneja & $\mathrm{x}$ & & $x$ \\
\hline Clelia plumbea & $x$ & & \\
\hline Dipsas mikanii & $x$ & & \\
\hline Dipsas aff. neuwiedi & $x$ & & \\
\hline Dipsas variegata & $x$ & $x$ & \\
\hline Echinanthera cephalomaculata & $x$ & & \\
\hline Echinanthera cephalostriata & $\mathrm{x}$ & & \\
\hline Erythrolamprus aesculapii & $x$ & $x$ & \\
\hline Erythrolmprus almadensis & $\mathrm{x}$ & & \\
\hline Erythrolamprus miliaris & $x$ & $x$ & $x$ \\
\hline Erythrolamprus poecilogyrus & $\mathrm{x}$ & $\mathrm{x}$ & $x$ \\
\hline Erythrolamprus viridis & $\mathrm{x}$ & $x$ & \\
\hline Erythrolamprus reginae & $x$ & $x$ & \\
\hline Helicops leopardinus & $x$ & $x$ & $x$ \\
\hline Imantodes cenchoa & $x$ & $x$ & \\
\hline Leptodeira annulata & $\mathrm{x}$ & $x$ & $x$ \\
\hline Lygophis dilepis & $x$ & $x$ & \\
\hline Oxyrhopus guibei & $x$ & & \\
\hline
\end{tabular}




\begin{tabular}{|c|c|c|c|}
\hline Oxyrhopus petolarius & $x$ & $x$ & \\
\hline Oxyrhopus trigeminus & $x$ & & $x$ \\
\hline Philodryas nattereri & $x$ & & $\mathrm{x}$ \\
\hline Philodryas olfersii & $x$ & $x$ & $x$ \\
\hline Philodryas patagoniensis & $\mathrm{x}$ & & \\
\hline Phimophis guerini & $x$ & & \\
\hline Pseudoboa nigra & $x$ & & $\mathrm{x}$ \\
\hline Psomophis joberti & $x$ & & $\mathrm{x}$ \\
\hline Siphlophis compressus & $x$ & $x$ & \\
\hline Taeniophallus affinis & $x$ & & \\
\hline Taeniophallus accipitalis & $x$ & $x$ & $\mathrm{x}$ \\
\hline Thamnodynastes almae & & & $x$ \\
\hline Thamnodynastes hypoconia & $x$ & & $\mathrm{x}$ \\
\hline Thamnodynastes pallidus & $x$ & $x$ & \\
\hline Thamnodynastes phoenix & & & $\mathrm{x}$ \\
\hline Thamnodynastes sertanejo & $x$ & $\mathrm{x}$ & \\
\hline Xenodon merremii & $x$ & & $x$ \\
\hline Xenodon rabdocephalus & $x$ & & \\
\hline Xenopholis undulatus & $x$ & & \\
\hline Total $=63$ & & & \\
\hline
\end{tabular}

Moreover, dry Brejos would have another origin related to dry forests that differ from those located to the east of the Borborema Plateau (Barbosa et al. 2008). The Brejos of Alagoinha, Belo Jardim, Arcoverde, and Sertânea compose a group of dry Brejos, probably owing to the presence of species such as Thamnodynastes phoenix, Thamnodynastes almae, Thamnodynastes sertanejo, Apostolepis cearensis, Erythrolamprus viridis, Boiruna sertaneja, and other species predominantly distributed in the Caatinga biome. The other set formed by humid Brejos present some species closely related to the Amazon and Atlantic Forest, such as Taeniophallus affinis, Dipsas variegata, Dipsas aff. neuwiedi, Thamnodynastes pallidus, Lachesis muta, Bothrops leucurus, Bothrops bilineatus, Drymoluber dichrous, Spilotes sulphureus. These differences in species composition are reflected in the separation of Brejos in dry and humid forests.

Because of the interface of Brejos with the Atlantic Forest and Caatinga, the scanty information related to the snake fauna of the region, and the complex species composition if the region, we performed a second analysis to elucidate how the snake fauna of Brejos is established compared with that of areas of the coastal Atlantic Forest and dry Caatinga (Figure 3 ).

Our analysis revealed a robust distinction between the Atlantic Forest and Caatinga; this segregation was expected because of the high number of endemic species in the Atlantic Forest and Caatinga. Six of the eight Brejos analyzed were closer to the Atlantic Forest, and only two were closer to Caatinga. The proximity of the six Brejos with the Coastal Atlantic Forest reinforced that the Brejos shared a high number of species and that the majority of these forests were closer to the northeastern coastal Atlantic Forest, as claimed by several previous botanical studies (Tabarelli and Santos 2004; Rodal et al. 2008; Rodal and Sales 2008; Thomas and Barbosa 2008). Only the Brejos of Arcoverde and Sertânea are located in the Caatinga areas, which can be explained by the presence of endemic species of Caatinga, such as Thamnodynastes almae, Thamnodynastes phoenix, Thamnodynastes sertanejo, and Bothrops erythromleas in those areas. In this second analysis, the separation between dry 


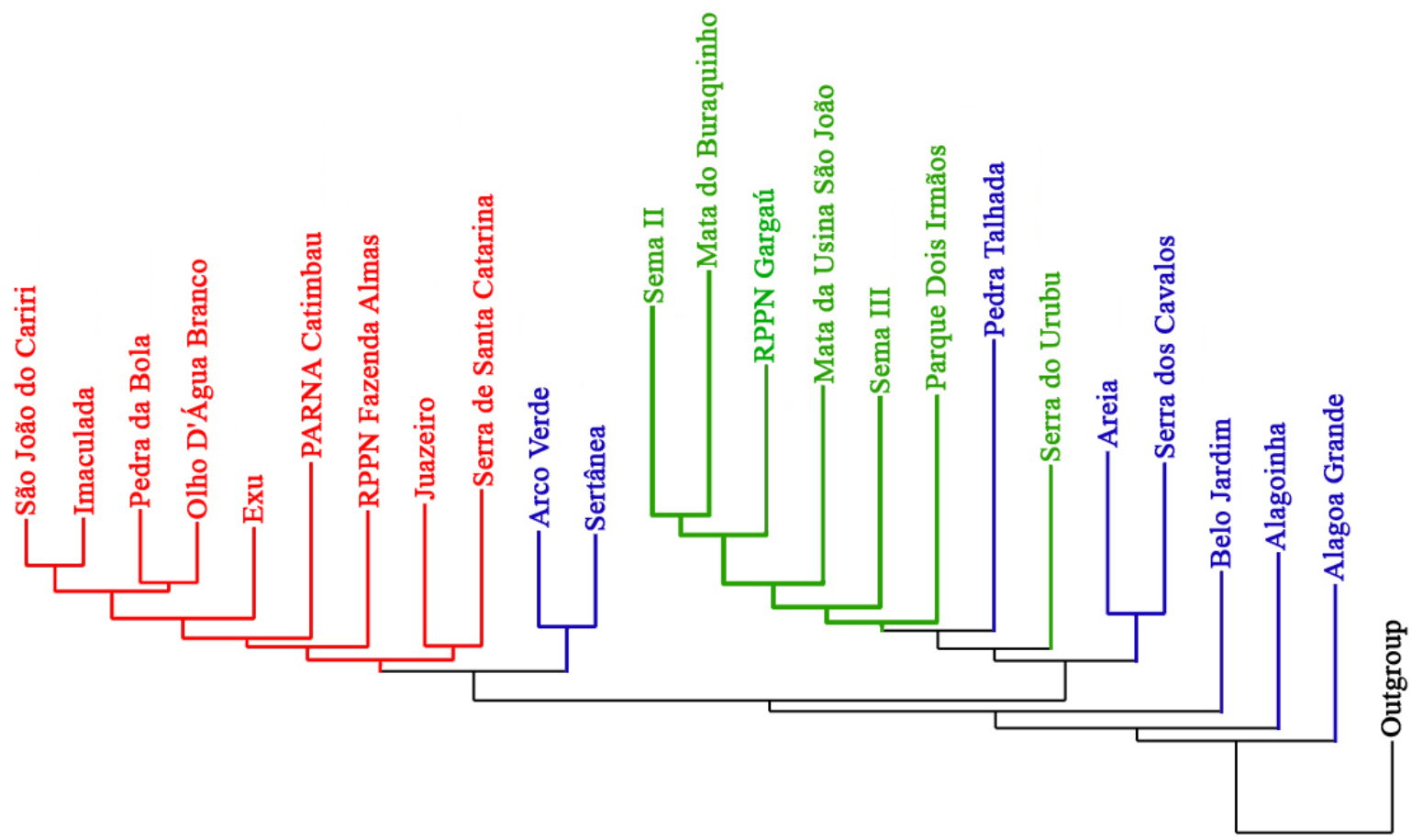

Figure 3. Neighbourn-joining analyses showing the relations of the Brejos de Altitude with the Atlantic Forest and the Caatinga. Caatinga in red, Northeastern coastal Atlantic Forest in green, The Brejos de Altitude in blue.

and humid Brejos was still maintained but to a small degree when the Brejos were analyzed separately.

Probably the high number of open-area species found in the northeastern coastal Atlantic Forest probably affected the resemblance factor among these areas. As stated by Pereira-Filho et al. (2017), the snake fauna of the PEC harbors a high number of species in open areas. Although, endemic species of Caatinga have not been recorded in the coastal fragments. Unfortunately, the vegetation between the coastal fragments of the Atlantic Forest and the Brejos de Altitude in the Borborema mountain range was almost destroyed, indicating intense human occupation and consequent deforestation (Barbosa et al. 2004; Pereira-Filho et al. 2017); thus, the relationship between these areas can only be analyzed speculatively.

The number of 63 species recorded in the Brejos represented $28,63 \%$ of the 220 species found in the Atlantic Forest biome (Pereira-Filho et al. 2017). Despite the high percentage of species, the isolated richness of each forest island is not well known. The richest Brejo assemblage is that of Pedra Talhada with 42 species, whereas the Brejo of Arcoverde showed low richness of 18 species (Table 4), although collection efforts, different methodologies, and conservation status of the areas can drastically affect these numbers. Comparisons of species composition among the Brejos are fundamental to establish conservation measures based on species richness, endemisms, and biogeographic history. Many inland forests suffer from great degradation owing to deforestation, habitat fragmentation, and illegal hunting, but surprisingly none of the 63 species recorded in the Brejos are listed in the national red list of threatened species, indicating a clear inadequacy of the evaluations and an urgent need for a list of regional threatened species 
Table 4. Most well-sampled Brejos in PEC with the species richness, total area and distance from the coast.

\begin{tabular}{|c|c|c|c|}
\hline Brejo de Altitude & $\begin{array}{c}\text { Area } \\
\text { (hectare) }\end{array}$ & $\begin{array}{l}\text { Species } \\
\text { Richness }\end{array}$ & $\begin{array}{l}\text { Distance from The } \\
\text { Coast (kilometers) }\end{array}$ \\
\hline \multicolumn{4}{|l|}{ Paraíba State } \\
\hline Areia - Mata do Pau Ferro & 600 & 26 & 98 \\
\hline Alagoinha & 200 & 22 & 73 \\
\hline Alagoa Grande & 600 & 19 & 87 \\
\hline \multicolumn{4}{|l|}{ Pernambuco State } \\
\hline Belo Jardim & 250 & 15 & 167 \\
\hline Pedra Talhada & 4.469 & 42 & 90 \\
\hline Sertânea & unknown & 22 & 286 \\
\hline Arco Verde & unknown & 18 & 231 \\
\hline Brejo dos Cavalos & 1.200 & 29 & 119 \\
\hline
\end{tabular}

to protect the natural populations in these areas.

A very important event must be mentioned as a main reason for forest devastation in northeastern Brazil. An institutional program named Proálcool was initiated in 1975 as a national effort aimed at substituting oil derivates with alcohol, resulting in deforestation and establishments of large-scale sugar cane plantations in areas originally covered by forests. This program had a strong impact not only on the Brejos de Altitude but on the entire PEC Atlantic Forest (Coimbra-Filho and Câmara 1996). To date, many remnants of the Atlantic Forest are surrounded by sugar cane plantations on the coast and inland. In states such as Alagoas, Paraíba, and Pernambuco, some of the largest Atlantic Forest remnants, such as Usina São João and Serra Grande in Paraíba and Alagoas, respectively, comprise of alcohol plants. However, the sugar cane cycle in northeastern Brazil is older, with records in the year of 1586 showing that the devastation and diversity loss of the PEC forests is immeasurable and is an old issue
(Mello 2014).

Brejos must be considered the most threatened natural areas of the Atlantic Forest. It is also the least explored and the most fragmented area, with specific regions completely deforested. Northeastern Atlantic Forest, particularly the PEC region, has the most deficient data on many zoological groups, and the snakes are no exception. The amount of information on snakes in the southeastern Atlantic Forest is much higher than that in the PEC region, with a great number of surveys conducted and ecological information available (Pereira-Filho et al. 2017). Another comparison clearly shows how the Brejos de Altitude is neglected. According to Freitas et al. (2020), there have been 47 herpetological surveys in the Brazilian Amazon, whereas in the Brejos, only eight areas are well sampled, even in the Brejos region that are easily accessible and even after research centers are built in all its extensions.

Advancing our knowledge of the snake fauna in the PEC is urgent to overcome the environmental problems responsible for the diminution of such special areas. 
Deforestation, forest fragmentation, and illegal hunting are well-known problems, although exploration of hydric resources is not well documented (Freitas et al. 2019). Brejos de Altitude is an important area with many hydric sources, and recently, mineral water companies are exploring these fountains. Most of the times, the forest is maintained because of the presence of important water bodies. Thus, sustainable use of these hydric resources is fundamental to avoid environmental problems. Exploration of these natural resources should generate subsidies to protect the forests once these resources become public patrimonies. It is necessary to create new conservation units and instigate studies in such an interesting region of the Atlantic Forest to protect what remains in this ecosystem.

It is also imperative to re-evaluate the number of Brejos and the conservation status of each one. The least general panorama was furnished by Vasconcelos Sobrinho (1971), who stated that there were 43 Brejos in the states of Ceará, Rio Grande do Norte, Paraíba, and Pernambuco, covering an area of $18.589 \mathrm{~km} 2$, and that after 50 years, there are still no recent data on the present number of Brejos nor the actual area covered by these inland forests. The area covered by Brejos is probably much smaller today owing to great anthropogenic pressures in those areas. Unfortunately, few conservational actions have been taken to protect the Brejos; thus, studies and conservation efforts of the biota of these isolated remnants are urgently needed. Protecting and studying the Brejos are the only way to assure the viability of such singular areas of the Atlantic Forest.

\section{ACKNOWLEDGEMENTS}

The authors are grateful to Arthur Abbeg for providing the map. We are also grateful to Hussam Zaher from the Museu de Zoologia da Universidade de São Paulo (MZUSP) and Gustavo Calazans from the Universidade Federal da Paraíba (CHUFPB) for the permission to examine the specimens under their care. FGRF thanks the financial support from the Conselho Nacional de Desenvolvimento Científico e Tecnológico (CNPq Universal Grant No 404671/2016-0).

\section{DATA AVAILABILITY}

The data used to support the findings of this research from the corresponding author upon reasonable request

\section{CONFLICT OF INTEREST}

The authors have no conflict of interest to declare

\section{CONTRIBUTION STATEMENT}

Conceived of the idea: GAPF, MAF, FGRF

Data analysis: GAPF, FGRF

Wrote the first draft of the manuscript: GAPF

Wrote the Final versions of the manuscript: GAPF, MAF, GJBM, WLSV, FGRF

Supervision: GAPF, WSLV, FGRF

\section{REFERENCES}

Abrantes SHF, Silva ET, Sousa ITF, Leite LS, Ramos-Abrantes MM, Lima JPR, Kokubum MNC (2018) Herpetofauna da Serra de Santa Catarina, Paraíba, Brasil. In: Araújo HFP, Vieira-Filho AH (eds) Biodiversidade na Serra de Santa Catarina-PB: uma proposta de criação do parque Estadual das Águas Sertanejas. 1 ed. João Pessoa: Editora UFPB, pp.101-139. 
Andrade-Lima D (1982) Present-day forest refuges In Northeastern Brazil. In: Prance GT (ed) Biological diversification in the tropics. Columbia University Press, New York, pp. 245251.

Andrade-Lima D. (1960). Estudos fitogeográficos de Pernambuco. Arq. Inst. Pesq. Agron. 5:305341.

Andrade-Lima D. (1966). Esboço fitoecológico de alguns "brejos" de Pernambuco. Inst. Pesq Agron. Nova Sér. Publ. Bot. Técn. Recife 8:3-27.

Barbosa MRV, Agra MF, Sampaio EVSB, Cunha JP, Andrade LA (2004) Diversidade florística da Mata de Pau Ferro, Areia, Paraíba. In: Kátia CP, Jaime JP, Cabral MT (eds) Brejos de altitude em Pernambuco e Paraíba: história natural, ecologia e conservação. Brasília: Ministério do Meio Ambiente, pp. 111-122.

Bigarella JJ (1975) The Barreiras Group in Northeastern Brazil. Anais da Academia Brasileira de Ciências 47: 365-393.

Coimbra-Filho AF, Câmara IG (1996) Os limites originais do bioma Mata Atlântica na Região Nordeste do Brasil. Fundação Brasileira para a Conservação da Natureza, Rio de Janeiro.

Costa HC, Bérnils RS (2018) Répteis do Brasil e sua s Unidades Federativas: Lista de espécies. Herpetologia Brasileira 8: 11 - 57.

Cunha OR, Nascimento FP (1978) Ofídios da Amazônia $X$ - As cobras da região Leste do Pará. Publicações Avulsas do Museu Paraense Emılio Goeldi 31: 1-218.

França RC, Germano CES, França FGR (2012) Composition of a snake assemblage inhabiting an urbanized area in the Atlantic Forest of Paraíba State, Northeast Brazil. Biota Neotropica 12: 183-195.

Freitas MA, Entiauspe Neto O, Lima TO, Silva Neto JS, Araujo D, Silva JMS (2016) Snakes of Juazeiro, Bahia, Middle of São Francisco River, Brazil. Boletim do Museu de Biologia Mello Leitão 38: 331-345.

Freitas MA, Abbeg AD, Araujo D, Coelho HEA Azevedo WS, Chaves MF, Rosa CM, Moura GJB (2019) Herpetofauna of three Brejos de Altitude in the interior of the state of Pernambuco, northeastern Brazil. Herpetology Notes 12: 591-602.
Freitas MA, Barbosa GG, Bernardino KP, Pereira-Filho JD, Abbeg AD (2019) First records of the rare snake Echinanthera cephalomaculata Di-Bernardo, 1994, in the state of Pernambuco. Herpetology Notes 12: 1005.

Freitas MA, Venâncio NM, Abbeg AD, Azevedo WS, Pereira VO, Zanotti AP, Veloso A, Schwarzbach L, Sousa AG, Cruz-da-Silva RC, Amorim VRG, Moura GJB (2020) Herpetofauna from the Estação Ecológica Rio Acre, Amazon Rainforest, Brazil. Herpetology Notes 13: $33-48$.

Guedes TB, Nogueira, CC, Marques OAV (2014) Diversity, natural history, and geographic distribution of snakes in the Caatinga, Northeastern Brazil. Zootaxa (Online) 3863: 193.

Lins RC (1989) As áreas de exceção do agreste de Pernambuco. Sudene, Recife, (Séries Estudos regionais).

Marques OAV, Eterovic A, Guedes TB, Sazima I (2017) Serpentes da Caatinga: guia ilustrado. 1. ed. Cotia: Ponto A.

Melo IV, Moura GJB, Freitas MA, Andrade EVE, Casal C, Abbeg AD, Kokubum MNC (2018) New additions to the herpetofauna of the Dois Irmãos State Park, an urban Atlantic Rainforest fragment in northeastern Brazil. Herpetology Notes 11: 245-254.

Mello JAO (2014) História da Paraíba. Ed. José Otavio de Arruda Mello

Myers N, Mittermeier RA, Mittermeier CG, Fonseca GAB, Kent J (2000) Biodiversity hotspots for conservation priorities. Nature 403: 845-853.

Pedrosa IMMC, Costa TB, Faria RG, França FGR, Laranjeiras DO, Oliveira TCSP, Palmeira CNS, Torquato S, Mott T, Vieira GHC, Garda AA (2014) Herpetofauna of protected areas in the Caatinga III: The Catimbau National Park, Pernambuco, Brazil. Biota Neotropica 14: 1-12.

Pereira Filho GA, Montingelli GG (2011) Check list of snakes from the brejos de altitude of Paraíba and Pernambuco, Brazil. Biota Neotropica 11: 1-7.

Pereira-Filho GA, Vieira WL, Montingelli GG, Rodrigues JB, Alves RRN, França FGR (2017) Diversidade. In: Pereira-Filho GA, Vieira WLS, Alves RRN, França FGR (eds) Serpentes da Paraíba. João Pessoa, pp. 55-269. 
Peters JÁ, Orejas-Miranda B (1970) Catalogue of the Neotropical Squamata pt. II: lizards and amphisbaenians. Bulletin of the United States National Museum 297: 1-347.

Prance GT (1982) Forest refuges: evidences from woody angiosperms. In: Prance GT (ed) Biological diversification In the tropics. Columbia University Press, New York, pp.137-158.

Rizzini CT (1963) Nota prévia sobre a divisão fitogeográfica do Brasil. Revista Brasileira de Geografia 24: 1-64.

Roberto IJ, Oliveira CR, Araújo Filho JA, Oliveira HF, Ávila RW (2017) The herpetofauna of the Serra do Urubu mountain range: a key biodiversity area for conservation in the brazilian atlantic forest. Papéis Avulsos de Zoologia (online) 57: 347-373.

Roberto IJ, Ávila RW, Melgarejo A (2015) Répteis (Testudines, Squamata, Crocodylia) da Reserva Biológica de Pedra Talhada. In: Studer A, Nusbaumer L, Spichiger R (eds). Biodiversidade da Reserva Biológica de Pedra Talhada (Alagoas, Pernambuco - Brasil). 1ed. Genebra: Boissiera 68: 357-375.

Rodal MJN, Barbosa MRV, Thomas WW (2008) Do the seasonal forests in northeastern Brazil represent a single floristic unit? Brazilian Journal Biology 68: 467-475.

Rodal MJN, Sales MF (2008) Panorama of the montane forests. Memoirs of the New York Botanical Garden 100: 535-553.

Rodrigues JB, Gama SCA, Filho GAP, França FGR (2015) Composition and Ecological Aspects of a Snake Assemblage on the Savanna Enclave of the Atlantic Forest of the Guaribas Biological Reserve in Northeastern Brazil. South American Journal of Herpetology (Impresso) 10: 1-8.

Sampaio ILR, Santos CP, França RC, Pedrosa IMMC, Solé M, França FGR (2018) Ecological diversity of a snake assemblage from the Atlantic Forest at the south coast of Paraíba, northeast Brazil. Zookeys 787: 107-125.

Vanzolini PE, Williams EE (1981) A quasehistorical approach to the natural history of the differentiation of reptiles in tropical geographic isolates. Papéis Avulsos de Zoologia 34: 189-204.

Vasconcelos Sobrinho J (1971) As Regiões Naturais do Nordeste, o meio e a civilização. Conselho de Desenvolvimento de Pernambuco, Recife.

Tabarelli M, Santos AMM (2004) Uma breve descrição sobre a história natural dos brejos nordestinos. In: Pôrto KC, Cabral JJP, Tabarelli $M$ (eds). Brejos de Altitude em Pernambuco e Paraíba: História natural, ecologia e conservação. Ministério do Meio Ambiente, Brasília, pp. 99-110.

Thomas WW, Barbosa MR (2008) Natural Vegetation Types in the Atlantic Coastal Forest of Northeastern Brazil. Memoirs of the New York Botanical Garden 100: 6-20.

Vasconcelos-Sobrinho, J. (1971) Os brejos de altitude $e$ as matas serranas. In: J. Vasconcelos-Sobrinho (ed.). As regiões naturais do Nordeste, o meio e a civilização. Conselho de Desenvolvimento de Pernambuco, Recife, pp. 79-86

Vitt LJ, Vangilder LD (1983) Ecology of snake community in the northeastern Brazil. Amphibia-Reptilia 4: 273-296

Zaher H, Grazziotin FG, Cadle JE, Murphy RW, Moura-Leite JC, Bonatto SL (2009) Molecular phylogeny of advanced snakes (Serpentes, Caenophidia) with an emphasis on South American Xenodontines: a revised classification and descriptions of new taxa. Papéis Avulsos de Zoologia 49: 115-153.
Received: 26 March 2020

Accepted: 28 April 2020

Published: 01 May 2020 


\section{ADDITIONAL FILES I. Voucher list}

Epictia borapeliotes (MZUSP 23063); Amerotyphlops arenensis (MZUSP 20248); Boa constrictor (MZUSP 22996); Epicrates assisi (MZUSP 20379); Bothrops leucurus (CHUFPB 0005050); Crotalus durissus (CHPUFRPE 4934); Micrurus ibiboboca (MZUSP 20287); Micrurus sp. (MZUSP 20428); Chironius exoletus (MZUSP 20414); Chironius flavolineatus (MZUSP 20237); Drymarchon corais (MZUSP 4922); Drymoluber brazili (MZUSP 7562); Leptophis ahaetulla (MZUSP 2303); Oxybelis aeneus (MZUSP 8954); Palusophis bifossatus (MZUSP 8939); Spilotes pullatus (MZUSP 20384); Tantilla melanocephala (MZUSP 20225); Dipsas aff. neuwiedii (MZUSP 20418); Erythrolamprus almadensis (MZUSP 23029); Erythrolamprus miliaris (MZUSP 9017); Erythrolamprus viridis (MZUSP 20317); Imantodes cenchoa (MZUSP 8897); Leptodeira annulata (MZUSP 9016); Ligophis dilepis (MZUSP 20236); Oxyrhopus guibei (MZUSP 20291); Oxyrhopus petolarius (MZUSP 20280); Oxyrhopus trigeminus (MZUSP 20277); Philodryas olfersii (MZUSP 20304); Philodryas nattereri (MZUSP 20368); Philodryas patagoniensis (MZUSP 23005); Pseudoboa nigra (MZUSP 4949); Psomophis joberti (MZUSP 23031); Taeniophallus occipitalis (CHUFPB 0005889); Thamnodynastes hypoconia (MZUSP 20312); Xenodon merremii (MZUSP 20403); Xenopholis undulatus (MZUSP 9100).

\section{ADDITIONAL FILES II. List of geographic coordinates used in the cluster analyses}

Atlantic Forest - Sema II (06044' 2.43" S / 35010'23. 89”W), Sema III (06048'17.83"S / 350 5'11.64"W), RPPN Gargau (0700'44"S / 340 57'25”W), Mata do Buraquinho (07008'40.10"S / 34051'23.10”W), Parque Dois Irmãos (08000'48.91"S / 340 56'40.24”W), Serra do Urubu (080 41'35.1'S, 35051'27.8"W)

Caatinga - RPPN Fazenda Almas (7028'15"S / 36052'51'W), São João do Cariri (7022'29"S, 36o31'55"W), Olho D'água (7o22'43"S / 36o31'29"W), Imaculada (7o20'46"S / 37o35'53"W), Pedra da Bola (7029'29"S / 36056'14"W), Serra de Santa Catarina (07000;11.6"W / 38013'28,4"W), Exu (07033'54.45"/ 39046'33.61"W), Parna Catimbau (08036',53.63"S / 3701303.29”W), Juazeiro (09²5'34"S/ 40³0'30"W)

Brejos de Altitude - Alagoinha (60 58'16. 70"S / 350 32'13. 48'W), Areia - Pau Ferro (60 58'13. 26"S / 350 44'39. 66"W), Alagoa Grande (60 59'56. 20"S / 350 44'39.66"W), Arco Verde (80 41. 84" S / 370 05. 85" W), Belo Jardim (80 33. 65"S / 360 42. 35"W), Brejo dos Cavalos (80 22' 37" S / 360 03'33" W), Pedra Talhada (90 13'12. 02"S / 360 25'20. 67"W), Sertânea (80 07. 56"S / 370 29. 93"W) 